\title{
竜昇殿鈗業所の水銀製鍊
}

\section{Metallurgy of Mercury at Ryüshoden Mine}

\author{
畑中 典 郎* \\ Sukeo HATANAKA
}

\section{1. 縉 言}

北進鉱業が北海道才ホーツク沿岸の漁港で知られた紋 別市郊外に水銀鉱石の採掘から精製水銀の生产寺で一貫 企業開始して5 年有余定経過したが, その間貿易の自 由化と水銀市場価格の激しい変動に耐光る体質づくりに 設備の合理化と安定した技術の開発をすすめてきた。

そのなかの水銀製鍊設備仁ついては前述の体質强化の ほかとく浪鉱害の防止々従業員の水銀中毒の絶無を果す ぶく，作業工程の簡略化在計るため日本鉱業技術管理部 の指導, 援助をもつて設備の拔本的な改造計画焉す寸 昭和 41 年改造工事は完結した。

工事の主なものは

1. 電気収じ装置の導入

2. ロータリクーラによる排涬処理設備

3. 排水処理設備

電気收じん装置について法水銀製鍊としては初のケー スであつたため, 多くの基礎調查や現地テス下を含めて いろいろと問題があつた。ロータリークーラによるキル ン排㵏処理および排水処理設備の合理化はおおむ水順調 江工事が進められ昭和 42 年 3 月から機能を充分飞表わす ことができた。結詞これらの設備の改造により鉱害の発 生要因と水銀中毒防止の危険性を取りのぞくことができ かつ直接コストダウンにも好影響孛与えて生産性注著し く向上されたものと考えている。

その後, 第 2 鉱床の開発も順調に進み増産のため最少 限度の設備の增強戞計り，昭和 42 年 12

月完成した。

設備增強の主なものは

（1）二次破砕比上る原鉱サイズの 均一化

（2）ロータリーキルン暗焼効率向 上のためキルンの改造

（3）コンデンサ配列変換汇よる给 却勃果の向上と一部堌設による玲却エ リアの充足

（4）排ガス中和設诺の增強 以上 4 項目の完成後は月間処理能力を

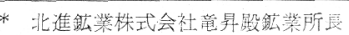

原鉱 $2,500 \mathrm{t}$

生産水銀量 7,238kg (210フラスコ) よつてこれまで 2 回にわたる改造走中心に竜昇殿水銀製 鍊の現況について報告する。

\section{2. 位置, 交通, 気候}

北海道紋別市上渚滑町中渚滑車盛が正式の住所である が交通注名奇本線紋別駅から南人6 km 標高 $100 \mathrm{~m}$ から $150 \mathrm{~m}$ の丘陵地帯で冬期積雪のときも自動車の運行が可 能で駅前から10分程度で到着する。

らな多に鉱業所従業員注全部紋別市内に居住し通勤は 市内営業バスを利用している。

年間の平均気温は紋別測候所調べでは $6{ }^{\circ} \mathrm{C} て ゙$ 盛夏には $30^{\circ} \mathrm{C}$ 超えることもあるが，湿度は低くしのぎ易い。し かし冬期は長く11月中句より量沙少なが降雪がある。 とくに1月上旬頃より 3 月上旬までの間, オホーツク海

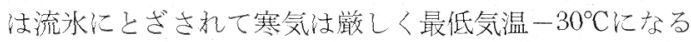
ことも珍しくない。積雪は比較的少なく平均 $1 \mathrm{~m} 50 \mathrm{~cm}$ 位で晴天の日が多く雨量, 降雪点含め年間 $600 \sim 800 \mathrm{~mm}$ で道内でも少ない地域に属する。

\section{3. 沿革}

当鉣山は昭和18年道路開さくのさい辰粒砂(いも辰眇) が発見され地元有力者某氏により開発を行ない北鎮鉣山 上命名，レトルト方式による製鍊操業が実施されたが操 業振わず休山した。その後昭和 29 年にいたり大车田鉱業

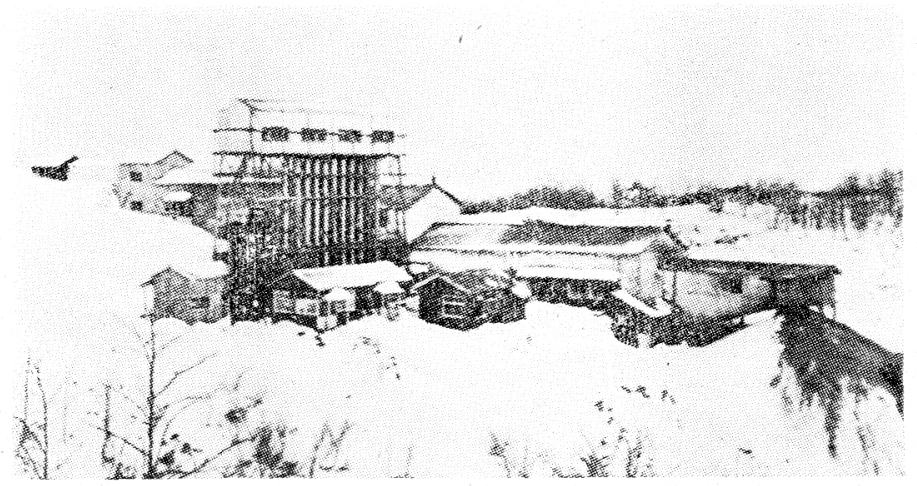

写真1竜昇殿鉱山製鍊場全景 
株式会社に引継がれ竜昇殿鉱山と改名し，ロータリーキ ルン方式による製鍊法を採用して生産を始めたが，これ また操業振わず昭和 34 年 12 月休山した。昭和 35 年10月当 社がこれを買収し11月探鉱所を開設探鉱に着手し, 約 1 年 8 カ月の間調查の結果埋蔵鉱量も確認され，また製鍊 方法はロータリーキルン方式による製鍊方式が水銀生産 の一貫企業として有利であるとの結論に達し，昭和 37 年 6 月より製錬設備の建設に着工し同年10月20日ロータリ 一キルンの火入式を挙行し, 以後本格的生産を開始, 途 中幾多の設備改造増強を経過して今日にいたつた。

\section{4. 生 産 規 模}

（1）昭和37年10日，スタート当初の製鍊能力は

$\begin{array}{ll}\text { 処理釷量 } & 1,000 \mathrm{t} / \text { 月 } \\ \text { 水銀生産量 } & 2,850 \mathrm{~kg} / \text { 月 }\end{array}$

（2）昭和39年 4 月，操業の安定化により

$\begin{array}{ll}\text { 処理鉱量 } & 1,100 \mathrm{t} / \text { 月 } \\ \text { 水銀生産量 } & 3,450 \mathrm{~kg} / \text { 月 }\end{array}$

（3）昭和 40 年 4 月，ロータリーキルン一部改造と排 熱回収等の収造により

処理鉱量

$\cdot 1,500 t / 月$

水銀生産量

$4,275 \mathrm{~kg} /$ 月

（4）昭和 41 年 10 月，製錬設備の合理化改造により
処理鉱量
$1,700 \mathrm{t} /$ 月
水銀生産量
$4,922 \mathrm{~kg} /$ 月

（5）昭和 42 年 10 月, 現行キルン 1 基をもつて最大限 生産設備の収造, 増強により

処理鉱量

$2,500 t /$ 月

·生産水銀量

$7,238 \mathrm{~kg} /$ 月

とちようどスタート当初の 2.5 倍の生産能力と なって現在にいたつている。

（6）人員関係 採掘関係は組員をもつて行ない，現 在人員は78名で若干の浮動がある。 総務，探查および製錬は直轄員であ つて製錬従業員の内容は職員 5 名, 鉱員11名，計16名

\section{5. 地質および鉱床}

当鉱山付近の地質は先白覀系（日高層群）と思われる 硬砂岩, 粘板岩, 輝緑凝灰岩, 珪岩層等を基盤とし, こ れを不整合に扮㧍う新第三系中新世〜鮮新世（モベッ層 群）と思われる砂岩, 砂質泥岩, 泥岩の累層からなつて いる。火成活動は上記累層をお㧍い鉱山付近を中心とし て発達する玄武岩と鉱山西南方約 $4 \mathrm{~km}$ の渚滑川西岸に 分布する流紋岩がみられる。鉱床は前記モベッ層群の中 位に発達する砂岩層を母岩とする鉱染状(一部層状), 脈 状をなす辰砂鉱床で単位鉱体は同一層準内に不規則塊状
をなして賦存する場合が多い。現在まで第一，第二鉱床 を把握しこれらを開発している。

\section{6. 製鍊操業系統むよび設備の概要}

原鉱を $25 \mathrm{~mm}$ 前後に粉砕してロータリーキルンに連結 給鉱し重油バーナをもつて最高温度 $700^{\circ} \mathrm{C}$ 程度として焙 焼する。原鉱の水銀はすべて辰砂 $(\mathrm{HgS})$ であるので充分 な酸化気圈の中に扔いてほとんど完全に分解して蒸気と なる。この蒸気をコットレルにより脱じんの上コンデン 少に導入して冷却すれば水銀は凝集する。これを回収し 精製水銀とする。排ガスはコンデンサ末端にあるフイル 夕によりミスト水銀を回収し, 最終的に法石灰石中和塔 に送り $\mathrm{SO}_{2}$ の中和を計つて大気に放出する。キルン廃 さいはロータリークーラにより残溜ガスの回収と熱の一 部回収を行ない空冷して排出し坑内充喤に, 残部は堆積 場へ般出している。排水は主として排ガス中和塔におけ る洗浄水であるが，コンデンサ凝結水とフイルター洗浄 水および場内床水洗水が統合し排水処理設備に送り, 沈 降, $\mathrm{pH}$ 調整の上繰返し用水としてコンデンサ冷却水, 中和塔, フイルタの洗浄水拉よびそのほか用水として使 用している。

当地は前述したように年間降雨量が $600 \sim 800 \mathrm{~mm}$ 程度 とまれにみる渴水地帯で山元では入浴, 飲料にもこと欠 く場合も珍しくなく，用水の繰返し使用は鉱害問題の発 生防止上にも有益である。

\section{7. 操 業 経 過}

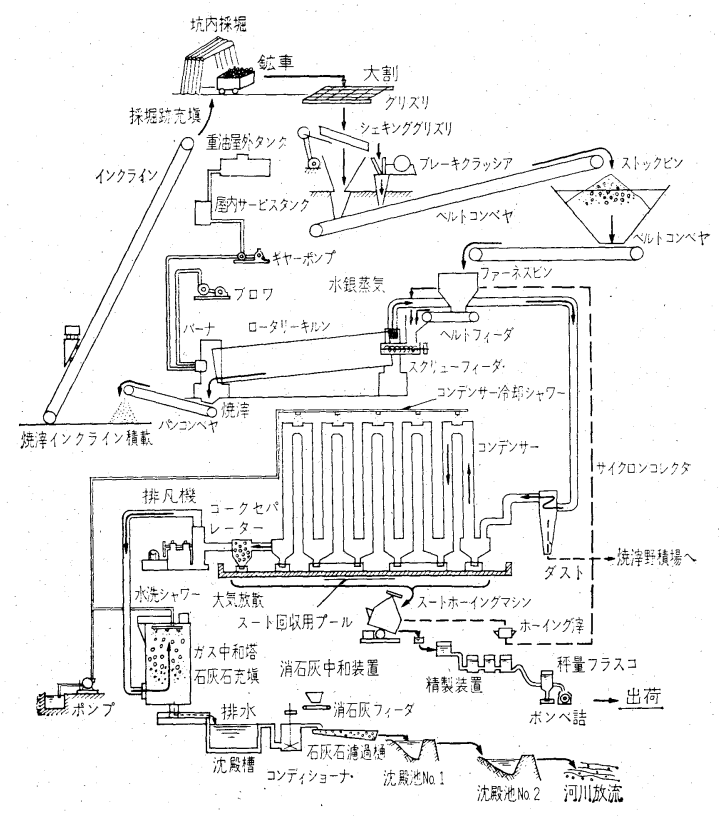

第1図製錬系統 図 
操業開始以来 5 力年間の推移経過の跡を数字をもつて 説明すると第 $1 \sim 3$ 表のとおりである。

第1表 原鉱品位の完全分析值（\%)

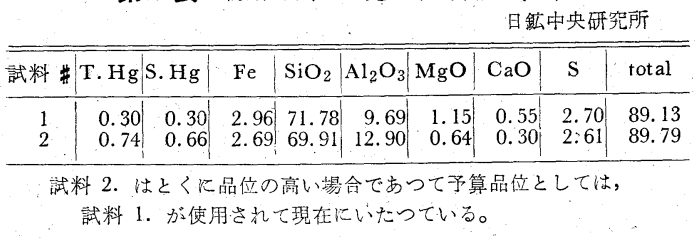

第 2 表 処理鉱量，生産水銀量执よび原単位の推移

(月平均)

\begin{tabular}{|c|c|c|c|c|c|}
\hline 年 & 処理鉱量 & 生産水銀量 & 重 油 & 電 カ & I 数 \\
\hline & $\begin{array}{c}\mathrm{t} \\
952\end{array}$ & $\begin{array}{l}\mathrm{kg} \\
2.946\end{array}$ & $\begin{array}{r}l \\
33.0\end{array}$ & $\begin{array}{l}\mathrm{kW} \\
20.7\end{array}$ & $0 . \frac{I}{41}$ \\
\hline 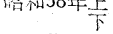 & $\begin{array}{r}1,052 \\
1,059\end{array}$ & $\begin{array}{l}2,946 \\
3,259\end{array}$ & $\begin{array}{l}33.0 \\
33.7\end{array}$ & 16.0 & 0.35 \\
\hline & 1,175 & 2,421 & 34.0 & 10.2 & 0.35 \\
\hline & 1,190 & 3,404 & 33.0 & 10.7 & 0.38 \\
\hline 40年上 & 1,448 & 4,513 & 31.5 & 11.0 & 0.28 \\
\hline & 1,578 & 4,203 & 28.5 & 9.5 & 0.26 \\
\hline 41年上 & 1,555 & 4,390 & 27.5 & 11.0 & 0.27 \\
\hline & 1,755 & 4,761 & 23.0 & 12.0 & 0.23 \\
\hline 42年上 & 1,725 & 4,931 & 25.5 & 13.5 & 0.26 \\
\hline
\end{tabular}

第3 表 コスト指数の推移

（昭和 41 年 1 月を 100 として月平均）

\begin{tabular}{|c|c|c|c|}
\hline $\begin{array}{r}41 \text { 年 } 1 \text { 月 } \\
2 \\
3 \\
4 \\
5 \\
6 \\
7 \\
7 \\
8 \\
9 \\
10 \\
11 \\
12\end{array}$ & $\begin{array}{r}100.0 \\
99.4 \\
110.0 \\
96.7 \\
95.5 \\
101.0 \\
99.0 \\
102.0 \\
97.0 \\
95.0 \\
95.7 \\
95.0\end{array}$ & $\begin{array}{c}42 \text { 年 } 1 \text { 月 } \\
2 \\
3 \\
4 \\
5 \\
6 \\
6 \\
7 \\
8 \\
9\end{array}$ & $\begin{array}{l}92.7 \\
96.5 \\
93.0 \\
90.0 \\
95.0 \\
92.5 \\
93.5 \\
93.0 \\
93.1\end{array}$ \\
\hline
\end{tabular}

以上データに示されたように生産量, 原単位およびコ ストの推移は製錬設備の改善の経過を物語つているが, つぎにその内容について概要をのべる。

\section{8. 製錬設備の合理化と設備増強の概要}

前述したように製錬設備の改善は主として鉱害の発生 防止と水銀中毒防止対策による作業行程の簡略化のため の設備の合理化を基礎にして検討を進め改善したのであ るが，これに付随して現行設備能力に掠いて最少限投資 をもつて最大能力の引出しをいかほど可能とするかにつ いて検討し増強したのである。

\section{$8 \cdot 1$ 電気収じん装置の導入}

水銀製錬に捛いてロータリーキルン等の焙焼炉から発 生した水銀蒸気を含むガスは一たん収じん装置を経て脱 じんした後, コンデンサに送入されスートとして粗水銀 を回収している。一般に水銀製錬の収じん装置としては サイクロンが使用されているが，当所においてもサイク ロン方式を採用していた（昭41年 8 月まで）。しかし母岩 が砂岩を主体としているため焙焼後におけるダストの発 生量は他の同型の製錬所と比較してかなり多く，かつサ イズも極めて微細でサイクロンの収じん効率はせいぜい
70 80\%程度で多くのスライムをコシデンサにおいて発 生していた。これがスートからの粗水銀分離工程，スラ イム処理工程等の後処理に種々な困難と手数をかけ, 取 扱いロスの増加, 繰返し物処理の増加による生産能力の 削減，および水銀精製工程の煩雑さから作業条件の悪化 と鉱害発生の危険性等の諸因をはらんでいた。さらに冬 期凍結期間が長いためスライムの回收处理にはより困難 を極めていた。よつて電気収じん装置を検討したが水銀 鉱石の焙焼ダストとしては電気固有抵抗が極めて高いこ と，コットレル内に扔ける水銀蒸気の凝結の懸念があつ てその導入にはかなり難しいとされ国内外の水銀製鍊に おける最初のケースであつたがメーカーの富士電機製造 株式会社の協力を得てテストコットレルによる共同研究 を現地で実施した。

8.1.1 ダストサイズの分布調查結果について 原鉱 が比較的もろい性質のためダストの微細化がサイクロン による捕収を困難とした原因で，そのサイン゙分布を第 4 表に示す。
第 4 表 ${ }^{a)}$

\begin{tabular}{|c|c|}
\hline サ イ ズ 別 & 分布率 \\
\hline 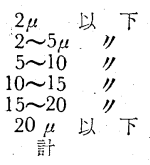 & $\begin{array}{r}9.5 \% \\
14.5 \% \\
46.0 \% \\
18.0 \% \\
7.0 \% \\
5.0 \% \\
100.0 \%\end{array}$ \\
\hline
\end{tabular}

第 5 表 ${ }^{\text {a) }}$

\begin{tabular}{c|r}
\hline+1 ズ別 & 分布率 \\
\hline $0.5 \mu$ 以 & $0.6 \%$ \\
$0.5 \sim 2.0 \mu$ & $40.0 \%$ \\
$2.0 \sim 5.0 \%$ & $49.0 \%$ \\
$5.0 \sim 10.0$ ” & $9.2 \%$ \\
$10.0 \mu$ 上 & $0.8 \%$ \\
棓 & $100.0 \%$ \\
\hline
\end{tabular}

すなわち $10 \mu$ 以下は70\%を占める。つぎに同サイクロ ンからコンデンサに飛んだダスト分布についてまとめる と第 5 表のと打りとなった。

すなわち $2 \mu$ 以下が $41.0 \%$ を占める。以上のよ.うに極 めて微細なダストであつてこれらを収じんするに適正な 収じん装置について検討したものでは，サイクロンによ る収じん範囲は大体 $2 \sim 15 \mu$ がもつとも効率が高いが， $2 \mu$ 以下ではほとんど収じん効果がないといえるので， より収じんを多くしょうとすればバッグフィルタか電気 収じん装置が必要となる。バッグフイルタは圧損失の大 とその圧変動差が大きいため焙焼炉の燃燒管理上不利な 点があると判断し，圧損失の少ない電気収じん装置を採 用したのである。

$8 \cdot 1 \cdot 2$ 電気収じん装置の現地テストについて ダス トの固有抵抗值についてはメーカー側の富士電機でテス トしたが第 2 図に示すように極めて抵抗值が高い結果が 判明した。すなはち $10^{11} \sim 10^{12} \Omega-\mathrm{cm}$. までは特殊な装置 を必要とする電気収じん装置の範囲であるので特別装置 をもつて抵抗值の引下げを計り
$200^{\circ} \mathrm{C}$ において
$6 \times 10^{11} \Omega-\mathrm{cm}$
$180^{\circ} \mathrm{C}$ $1 \times 10^{12} \Omega-\mathrm{cm}$ 


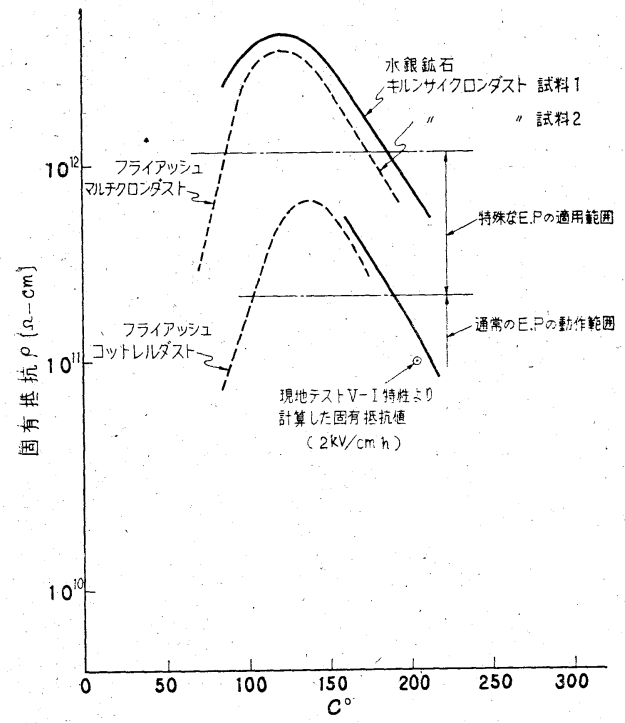

第 2 図、水銀鉱石焙焼ダス卜固有抵抗一温度特性 とするものを $1 \times 10^{11} \Omega-\mathrm{cm}$ に成功し，テストによる V.I 特性によつて電気収じん装置の適用が一応可能で あるとの結論を得た。

$8 \cdot 1 \cdot 3$ 装置の配置と仕様について 電気収じん装置 は従来のサイクロンの位置に設置し, サイクロンはバイ パス回路として別にダクトをもつて並列に配置し適時両 者を使用できるよらにした。

電気収じん装置の仕様は

型式UMC-21S（ユニット型）

ガス量 $\quad 25 \sim 27 \mathrm{Nm}^{3} / \min$ (Dry)

ガス温度 $220^{\circ} \mathrm{C}$

ガス成分 $\mathrm{CO}_{2} \quad 12 \% \quad \mathrm{O}_{2} 7 \% \quad \mathrm{SO}_{2} 3 \%$

ダスト量 $35 \sim 40 \mathrm{~g} / \mathrm{Nm}^{3}$

粒度分布 $1 \sim 3 \mu: 60 \% ，>3 \mu: 40 \%$

水分 $160 \mathrm{~g} / \mathrm{Nm}^{3}$

直流電源 $35 \mathrm{kV}$

$80 \mathrm{~mA} / 1 \phi 3.2 \mathrm{kVA}$

交流電源 $200 \mathrm{~V} 50 \mathrm{c} / \mathrm{s}$

限流リアクトル付セレン整流器 2 台 以上のほか電極のハンマーは全て電磁式となつている。

8・1.4 操業経過について 予備テストを経て操業を 開始したのであつたが当初はトラブルの連続でそのつど 改造を加え, 結局水銀製錬として特殊な性能を具備した 上コットレルとしての本来の高い収じん効率の機能が成 立した。

機能テストは主として収じん効率の検定を重要点とし てきたが第 6 表は荷電電圧(一次)条件を 3 段階に分けた 結果を要約したものである。以上の結果，安定した操業 に入ることができ，水銀蒸気を含有したガス中のダスト をカットオフリミット以下に捕収し排出しコンデンサに

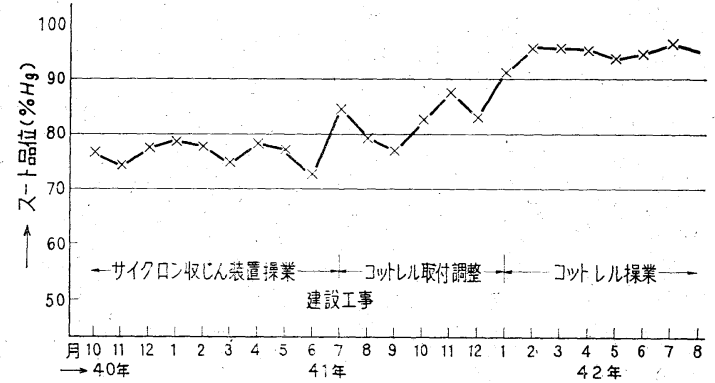

第3図コンデンサ回収スート品位の推移

第6表 収じえ効率テスト結果

\begin{tabular}{|c|c|c|c|c|}
\hline \multirow[t]{3}{*}{ No. 1} & \multicolumn{2}{|c|}{ コットレル出口含しん量 } & 一次電圧（特高） & \multirow{2}{*}{$\begin{array}{c}\text { 一次電流 } \\
8.5 \mathrm{~A} \\
\text { " } \\
\text { " } \\
\text { " }\end{array}$} \\
\hline & $\bar{X}$ & $\begin{array}{l}0.242 \mathrm{~g} / \mathrm{Nm}^{3} \\
0.298 \mathrm{~J} \\
0.251 \quad \mathrm{~J} \\
0.264 \quad \mathrm{~J}\end{array}$ & $\begin{array}{l}144 \mathrm{~V} \quad(22 \mathrm{kV}) \\
145 \mathrm{\prime \prime}(22 \mathrm{\prime \prime}) \\
150 \mathrm{\prime \prime}(23 \mathrm{\prime \prime}) \\
146 \mathrm{\prime \prime} \quad(22 \mathrm{~J})\end{array}$ & \\
\hline & \multicolumn{2}{|r|}{ 収じえ効率 } & $99.2 \%$ & \\
\hline \multirow[t]{2}{*}{ No. 2} & & $\begin{array}{l}0.345 \mathrm{~g} / \mathrm{Nm}^{3} \\
0.435 \quad \prime \prime \\
0.441 \quad \text { "J } \\
0.408 \quad \text { J }\end{array}$ & 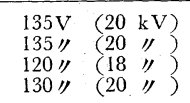 & $\begin{array}{c}2.7 \mathrm{~A} \\
\text { "I" } \\
\prime \prime \prime\end{array}$ \\
\hline & \multicolumn{3}{|c|}{ 収じん効率 } & \\
\hline No. 3 & & $\begin{array}{l}0.291 \mathrm{~g} / \mathrm{Nm}^{3} \\
0.327 \quad \text { " } \\
0.274 \\
0.297 \text { " }\end{array}$ & $\begin{array}{ll}139 \mathrm{~V} & (21 \mathrm{kV}) \\
140 \prime & (21 \mathrm{\prime}) \\
140 \prime \prime & (21 \mathrm{\prime \prime}) \\
140 ”(21 ") & (21)\end{array}$ & $\begin{array}{l}3.3 \mathrm{~A} \\
3.5 \mathrm{\prime \prime} \\
4.0 \mathrm{\prime \prime} \\
3.6 \mathrm{\prime \prime}\end{array}$ \\
\hline
\end{tabular}

おける処理工程を極めて簡略することができた。すなわ ちコンデンサに送入するダストの激減から回収されるス 一トの状況が従来のサイクロン方式に対して一変した。 第 3 図はスート品位の推移を示すものであるが，従来は $70 \% \mathrm{Hg}$ の品位であつたスートは熱処理によりスートホ 一イングマシンにて水銀を凝集分離して粗水銀としてい たがコットレル導入後はスートの品位が一躍 93〜98\% $\mathrm{Hg}$ でほとんど全量水銀のみとなり，従来の熱処理によ る分離方法をやめて湿式機械化により容易に粗水銀が得 られる状態となつた。このようにスートの処理工程が簡 略化された結果, 有害雲囲気での暴露作業時間が從来の 1/3に短縮され作業内容も安全化したので, 従来のホーイ ングに比較して水銀中毒の危険性は全く影をひそめ，作 業員の健康管理の一環として実施している尿中水銀量の 含有が一段と少なくなつてきたことからも確認された。 ちなみに第 7 表に作業員の尿中水銀量の推移を示す。つ ぎに生産性の向上は必然的に表われたことは前述したと おりであるが，設備の増強にはたえず自動化を計り工数 の増加をさけてきた。近日中にキルンの自動然焼化が完 成する見込みであるが，さらに電気収じん装置の適正荷 電圧の操作を操業条件と自動的に適合させる操作のロボ ット化を検討中である。

\section{$8 \cdot 2$ ロータリークーラーによる廃滓処理設備の合 理化}


第 7 表 従業員尿中水銀量分布比
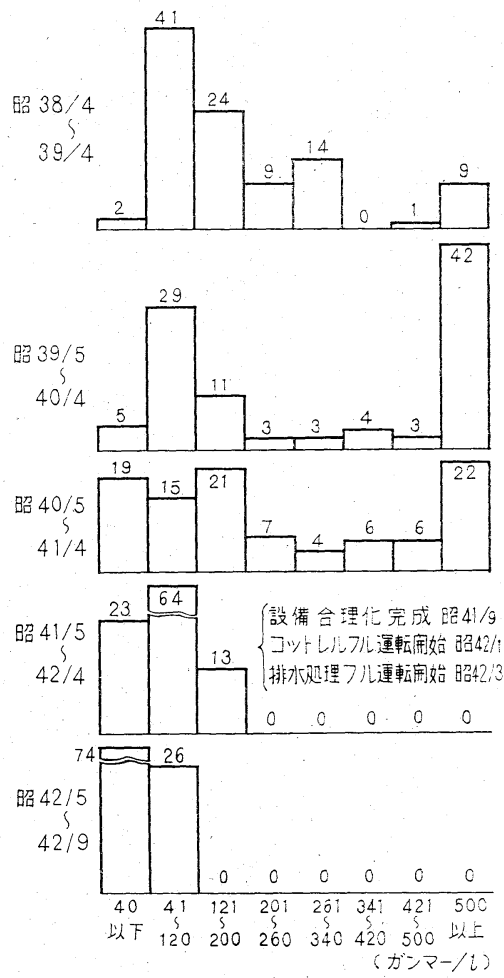

キルン廃涬は従来パンコンベヤにより直接室外に搬出 されていたが，400 450 $\mathrm{C}$ あて有害な水銀の残留ガス や $\mathrm{SO}_{2}$ ガスが周囲に拡散し鉱害発生の徴候を表わして いた。とく有害な水銀蒸気の屋内侵入むかなりあつて 作業環境を污染していた。よつてこの廃㳯をロータリー クーラ $(850 \mathrm{~mm} \phi \times 1,200 \mathrm{mmL})$ に自動給鉱し廃㳯に包含 されている有害ガスをことごとくキルンにドラフトし， キルン発生ガスとともにコンデンサに導入するように した。その結果廃㳯は同クーラにより夏期は $170^{\circ} \mathrm{C}$ に, 冬期は $70^{\circ} \mathrm{C}$ 亿泠却されて排出し，たい積あるいは坑内充

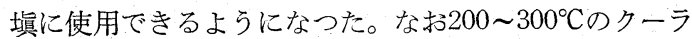
排ガスの一部をキルンバーナの二次空気に導入するよう にしてから，重油の使用量は従来にくらべて $22 \%$ 節減で きた。

\section{$8 \cdot 3$ 排水処理設備の合理化}

排水処理は前述したように排ガス中和塔，コンデンサ および場内床水洗等を統合して行ならのであるが，従来 は固形物の沈降を計つたのち消石灰を添加し $\mathrm{pH}$ 調整し て沈殿池にて清澄を計り河川に放流していたが，沈殿池 における沈降機構も不充分な上，スライムの多量発生も あって，排水処理機能としては不充分で釷害発生の危険 も伴つていた。また前に述べたように水資源の乏しさか ら排水の繰返し使用がのぞまれていた。しかしスライム の多量発生下では排水処理設備も大きくなりかっ冬期の
長い凍結期においてはスライムの回收は極めて困難なも のである。これが今回の電気収じん装置の導入に成功し ダストのスライム化が激減したことから排水処理は極め て容易となりかつ用水の繰返し使用が可能となって宿命 的な用水不足の悪条件を解決した。さらに河川に放流す る余剩水も僅少となつたので鉱害についても全く䀣念が なくなつた。さて，この合理化設備では前述した各排水 を濃縮タンク $(3 \mathrm{~m} \phi)$ に送入し凝集迅速沈降を計りスピ ゴットはフイルタープレスにより脱水しケークとしてキ ルンに繰返し，清澄水はシックナ $(4 \mathrm{~m} \phi)$ に送入し消石 灰ミルクを添加して $\mathrm{pH}$ 調節し全量をポンプアップして 用水として再使用する。ちなみに排水中，水銀のイオン 化したものはアルカリ処理により除害できることを確認 されているのでら $\mathrm{pH}$ を 8 9 辺に過剩気味の消石灰を添 加している。第 8 表は懸だくあるいは加溶された水銀を 水酸化物として他の塩基物とともに共沈する傾向を確認 するものであるb)。

第 8 表 懸だくおよび加溶水銀量と $\mathrm{pH}$ 值の関係

\begin{tabular}{|c|c|c|c|}
\hline 試料 \# & $\begin{array}{c}\text { 消石兏洣加量対試料 } \\
500 \mathrm{cc}\end{array}$ & $\begin{array}{l}\text { 消石灰添加後の } \\
\text { 沪夜 } \mathrm{pH} \text { 值 }\end{array}$ & 洰液中の水銀含有量 \\
\hline $\begin{array}{c}\text { 原 } \text { 液 }^{1} \\
2 \\
3 \\
4 \\
5 \\
6 \\
7 \\
8\end{array}$ & $\begin{array}{l}0 \mathrm{mg} \\
10 \\
20 \\
40 \\
80 \\
100 \\
200 \\
400 \\
800\end{array}$ & $\begin{array}{r}3.0 \\
3.7 \\
3.1 \\
3.2 \\
3.1 \\
3.1 \\
9.9 \\
13.0 \\
13.0\end{array}$ & $\begin{array}{l}5.9 \mathrm{mg} / l \\
2.14 \\
2.49 \\
2.36 \\
2.80 \\
2.85 \\
1.35 \\
<0.01 \\
<0.01\end{array}$ \\
\hline
\end{tabular}

\section{$8 \cdot 4$ 設備增強}

（1）粉砕設備 原鉱粉砕は従来からブレーキクラ ッシャによる一般破砕であつたが，25mm フルイにより 全量をふるい分けしプラスサイズをインペラーブレーカ

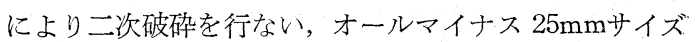
としてキルン給鉱能率と焙焼効率の向上計つた。

（2）焙焼設備 焙焼効率の上昇を計るため一部燃 焼室の改造とキルン内レンガ改造により焙焼効率の低下 することなしに，キルン容積率を増加させた。この結果 スタート当初の 2.5 倍の処理能力をむつにいたつた。

（3）コンデンサ関係 水銀蒸気がコンデンサにお いて冷却凝結する分布実態を把握し, 冷却効果と水銀回 収の相関を検討した結果，従来のコンデン开の配列を変 更することにより冷却効果の向上が確認された。よつて ロータリーキルンにおける最大処理能力と, 夏期におけ る最高気温を勘案して冷却エリアの充足を加えコンデン 少設備の合理化をした。

（4）排ガス中和設備 処理鉱量の増加に伴う排ガ ス量の増加により亜硫酸ガスの吸収装置の検討をした結 果, 現行石灰石中和法がより経済的, かつ吸收効果も有 効であることが実証されてきたので，同型の中和塔を 1

b）日鉱中央研究所 昭39，中研第2555号より 
基值列配置として増設した。よつて亜硫酸ガスの吸収率 は90〜95\%を維持できて鉱害の発生はない。

\section{9. むすび}

わが社としては当所の開発をもつて新たに水銀の生産 を経験したのであるが，これにいたるまでは，自らの苦 心もさることながら同業他社の親切なアドバイスがあり これによつて企業開始して日なお浅きにかかわらず，企 業の安定したことに対してここに深い謝意女のべる次第 である。また親会社である日本鉱業技術管理部の適確な る助言，指導を戴き設備の近代化を計ることができたこ と和今後とも企業在桩大伸張させる上に大きな障壁と
なる鉝害問題と労衝衛生の面に全く䀣念のなくなつたこ とを感謝するものである。さらに富士電機製造株式会社 の熱心な協力を謝乙当社米村前社長初め役員が現地に再 度おもむき，暖い励ましにより現地從業員の期待と熱意 がタのつた結果であることを記すものである。今後7、銀 の需要法ますます伸長するものと考えられるが, 生産側 としては国内資源の有効な活用之海外の困難な原鉱处理 を開発させ，国内水銀価格の安定に少しでも等与したい 所存である。よつて今後はさらに一段と生産技術の改善 合理化により一層のコストの切下げをはかるべき䞥勢に あることを䜅識し，わが国産業界の発展に微力をささげ たいと考える次第である。

\title{
イトムカ鉱山に抢ける水銀製鍊について \\ Outlines of Mercury Smelting at Itomuka Vine
}

\author{
正会員魯住力太郎* 正会員岡本 肇** \\ Rikitarō UOZUMI \\ Hajime OKAMOTO
}

\section{1. 緒言}

\section{1・1、位置および交通}

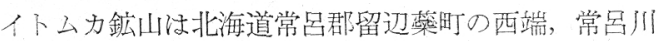
の一支流、武華川の上流に位置する。

交通は留辺樊駅より武華川に治い，国道39号起 37.5 $\mathrm{km}$ 溯行すると鉱山事務所, 選鉱場, 製鍊場の所在地で ある大町に達し，この閒バスで約40分を要する。本山採 鉣現場は大町よりさらに $8 \mathrm{~km}$ 上流に位置し, 本山採鉱 事務所より東方約 $1 \mathrm{~km}$ 下流で, 旭川一大雪山一北見学 結ぶ国道にバス括よびトラックで連絡される。

\section{2. 沿革}

本鉣山の位置する武華川上流地带は炤和の补期, 特別 交通不便なため，地下資源は未調查の区域であつたが， 昭和11年の大暴風雨による多数の風倒 木の発生, 翌年これら風倒木の搬出道 路開さく中, 表士中より拳大の辰砂塊 (いも辰砂) が発見されたことが, 本 鉣山開発の端緒である。

その後昭和 13 年北海道工業試験場地 質調查部により，有望な水銀大鉱床で あることが確認され，ヤマト鉱業株式 会社により昭和14年からイトムカ鉣山 の開発が着手され坑外探鉣の結果, 本

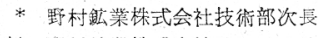

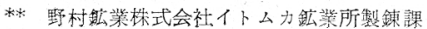

邦随一の大規模な鉱床が発見された。当時は戦時下のた め, 急速な増産がなされ, 本邦水銀生産の大部分支占め るにいたつた。

終戦と同時に乱掘の整㒉と需要激減から規模を縮少し ていたが，昭和27年世界市場の好転と新鈖脈の発見によ り，再び活沅を呈し現在にいたつている。

\section{2. 製鍊操業の概要}

操業系統の概要は第 1 図, 処理成績は第 2 図に示す。 粗鉣は坑内鉣と露天鉣の 2 種に大別される。イムパク トブレーカーウオッシングドラムートロムメれークラッ シフアイヤ等在経て湿式破硴され，それぞれミル采統一 シックナ等を経て浮選で精鉣を浮鉱として得る。製錬原 鉱はこの浮選精鉱が対象となる。

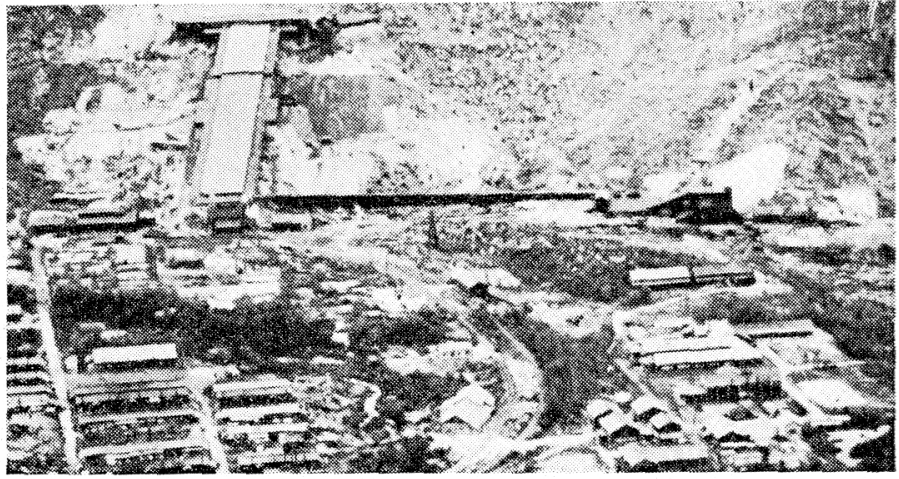

写真1イトムカ鉱山製鍊所全景 